\title{
KARAKTERISASI BATUAN BIJIH EMAS
}

\author{
Siti Aminah \\ Staf Pengajar Jurusan Teknik Mesin Fakultas Teknik, Universitas Jember \\ Email: siti33598@gmail.com
}

Naskah diterima: 20 November 2018 ; Naskah disetujui: 31 Desember 2018

\begin{abstract}
ABSTRAK
Emas merupakan komoditas utama yang selalu diincar oleh banyak bangsa. Di Indonesia, keberadaan pertambangan emas menyebar dan di setiap daerah yang mengandung deposit bijih emas memiliki karakter dan sifat yang berbeda-beda. Sifat dan karakter yang suatu bijih emas sangat menentukan proses ekstraksi emas selanjutnya, sehingga perlu dilakukan uji karakterisasi terlebih dahulu. Uji karakterisasi batuan bijih emas yang dilakukan terhadap contoh sampel meliputi analisis mineragrafi, X-Ray Fluorescences (XRF), X-Ray Diffraction (XRD), dan Fire Assay. Uji mineragrafi menunjukkan bahwa keberadaan emas berasosiasi dengan perak dalam bentuk elektrum dan tersebar secara acak sebagai inklusi dengan kuarsa, berwarna putih krem dan berukuran sangat halus hingga $5 \mu \mathrm{m}$. Mineral lain yang terkandung dalam bijih emas antara lain kalkopirti, spalerit, kovelit, pirit dan kuarsa yang merupakan komponen terbesar, yaitu 97. 98\%. Kandungan emas dalam bijih adalah 5,2 ppm.
\end{abstract}

Kata Kunci : Emas, karakteristik, kadar, XRD, XRF

\section{PENDAHULUAN}

Emas merupakan logam mulia yang banyak digunakan dan memiliki peran penting dalam kehidupan manusia. Emas termasuk ke dalam golongan logam mulia karena keterdapatannya di bumi yang langka dan memiliki sifat spesifik tertentu. Emas dapat ditemukan dalam bentuk mineral dimana emas sebagai logam berharga yang dominan, misalnya logam (native), electrum, calaverite, sylvanite dan mineral dimana emas sebagai unsur minor, misalnya arsenopyrite, pyrite, chalcopyrite, dan lainnya. Berdasarkan kemudahannya diekstraksi, bijih emas diklasifikasikan menjadi bijih emas free-milling, bijih emas kompleks dan bijih emas refraktori. Bijih emas free-milling dapat diolah dengan metode sianidasi konvensional dengan ukuran yang tidak terlalu halus. Untuk bijih emas kompleks akan memerlukan konsumsi reagen pelindi yang lebih banyak selama proses sianidasi sementara bijih emas refraktori memerlukan proses pre-treatment terlebih dahulu sebelum pelindian.

Uji karakterisasi perlu dilakukan terlebih dahulu, sebelum proses pelindian, agardapat diketahui struktur dan komposisi batuan tersebut. Dalam pengujian tersebut, dapatpula dilihat bagaimana sifat-sifat kimia dan fisika dari batuan bijih, klasifikasi mineral dan keberadaan mineral asosiasinya. Apabila sudah dilakukan uji karakterisasi, maka penentuan metode ekstraksi emas dapat disesuaikan.
Uji karakteristik yang digunakan dalam penelitian ini dengan menggunakan teknik analisis Atomic Absorbance Spektrophootometry (AAS), mineralogi, X-Ray Flourescence (XRF), X-Ray Diffraction dan Fire Assay. Penggunaan beberapa teknik analisis ini bertujuan agar hasil yang didapatkan menjadi lebih efisien dan akurat sehingga nantinya dapat digunakan sebagai acuan dalam pembuatan tambang maupun teknik ekstraksi yang digunakan.

\section{METODOLOGI}

Penelitian dilakukan untuk mempelajari karakterisasi dari batuan bijih yang mengandung emas. Sebelum dilakukan uji karakterisasi, sampel akan dipreparasi terlebih dahulu. Sampel bijih as received dikeringkan di dalam oven selama 24 jam untuk menghilangkan kadar air di dalam bijih. Preparasi dimulai dengan menghancurkan semua bijih menggunakan jaw crusher, roll crusher dan grinding hingga didapatkan ukuran bijih $\mathrm{P}_{80}-200 \#$. Semua bijih dicampur dan dihomogenisasi dengan menggunakan rotary splitter pada berbagai ukuran sehingga akan dihasilkan paket-paket contoh bijih yang sudah homogeny dan siap digunakan untuk proses penelitian selanjutnya. Paket-paket bijih ini akan digunakan untuk uji karakterisasi.

Karakterisasi bijih dilakukan terhadap sampel bijih untuk mengidentifikasi jenis dan sifat dari bijih yang akan digunakan untuk penelitian. Analisis mineragrafi sayat poles dilakukan untuk 
menentukan letak dan ukuran emas dalam bijih serta mineral pengikutnya. Analisis komposisi unsur kimia dalam bijih dilakukan dengan $X$-Ray Fluorescence (XRF) dan Fire Assay. Identifikasi jenis mineral dominan yang terdapat dalam bijih dilakukan dengan analisis X-Ray Diffraction (XRD).

\section{HASIL DAN PEMBAHASAN}

\section{Hasil Karakterisasi Sampel}

Penelitian ini diawali dengan uji mineragrafi. Dalam analisis mineragrafi, contoh sampel perlu dibuat preparat yang sesuai agar analisis dilakukan dengan baik. Preparat yang digunakan dalam analisis adalah sayatan poles. Pengambilan gambar dilakukan di bawah cahaya pantul Nikon Eclipse 50 iPol. Dari hasil pengamatan mineragrafi, diketahui bahwa bijih sampel sebagian besar terdiri dari kuarsa, serta sedikit mineral sulfide yaitu kalkopirit, spalerit, pirit, dan kovelit. Dalam bijih ini juga ditemukan kalsit, yang dapat berpotensi menyebabkan sifat preg-robbing. Mineral emas secara megaskopis tidak terlihat, akan tetapi pada pengamatan mineragrafi ditemukan keberadaan emas dalam bentuk mineral electrum. Mineral electrum yang ditemukan jumlahnya sangat sedikit dan memiliki kenampakan warna putih krem, berukuran sangat halus hingga $5 \mu \mathrm{m}$ yang tersebar secara acak dan terinklusi dalam kuarsa.

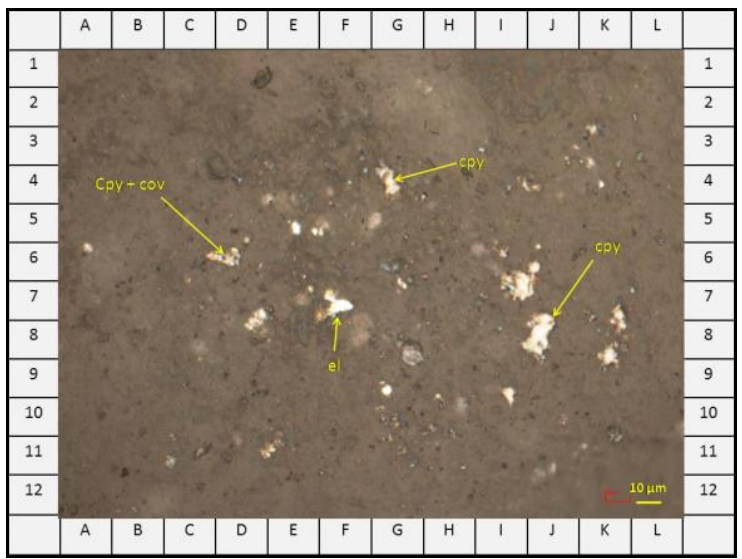

Gambar 1 Mikrografi sampel A, dibawah mikroskop refleksi, Kumulat inklusi detritus mineral sulfida dalam kristal kuarsa urat, cov = covellite, cpy $=$ chalcopyrite, el $=$ electrum

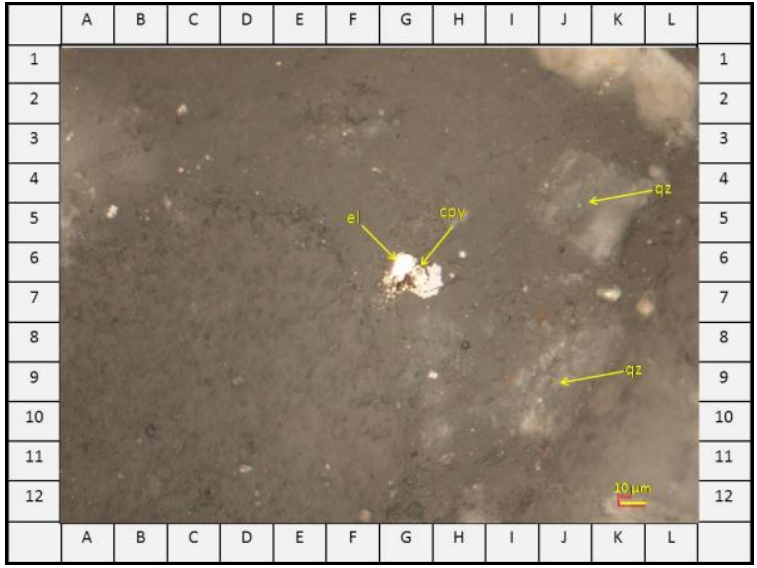

Gambar 2 Mikrografi sampel A, dibawah mikroskop refleksi, Detritus sulfide mengandung elektrum, $\mathrm{qz}=$ quartz, $\mathrm{cpy}=$ chalcopyrite, $\mathrm{el}=$ electrum

Hasil pengujian mineragrafi menunjukkan deskripsi mineral apa saja yang terkandung di dalam sampel, sebagai berikut:

1. Chalcopyrite : $<1 \%$, berwarna kuning bros, pecahan granuler tidak beraturan, berukuran sangat halus hingga $50 \mu \mathrm{m}$, sebagian besar mengalami ubahan menjadi kovellit, tersebar secara acak sebagai inklusi dalam kuarsa.

2. Sphalerite $:<1 \%$, berwarna abu abu, bentuk detritus tidak beraturan, berukuran halus hingga $40 \mu \mathrm{m}$, tersebar secara acak sebagai inklusi dalam kuarsa.

3. Covelite : $<1 \%$ berwarna abu abu kebiruan, bentuk detritus tidak beraturan, berukuran halus hingga $40 \mu \mathrm{m}$, sebagai hasil ubahan dari kalkopirit, tersebar secara acak sebagai inklusi dalam kuarsa.,

4. Pyrite : $<1 \%$, berwarna kuning putih, bentuk granuler dan detritus tidak beraturan, berukuran hingga $50 \mu \mathrm{m}$, tersebar secara acak sebagai inklusi dalam kuarsa.

5. Argentite/acantite $:<1 \%$, putih , kristalin berukuran halus hingga $100 \mu \mathrm{m}$, berasosiasi dengan kuarsa detritus dan kristal dalam jalur urat.

6. Electrum: $<<0,01 \%$, trace, putih krem, berukran sangat halus hingga $5 \mu \mathrm{m}$ tersebar secara acak sebagai inklusi dalam kuarsa.

7. Quartz : 97 -98 \%, putih, bening, abu abu (megaskopis), abu abu gelap (mikroskop refleksi), berupa detritus berukuran kasar hingga beberapa $\mathrm{cm}$ dan berupa kristalin prismatik panjang, dan membilah $50 \mu \mathrm{m}$. membentuk 
banding (layer layer, mengandung inklusi detritus sulfida sekunder berukuran sangat halus.

Tabel 1 Komposisi unsur yang terkandung dalam contoh sampel

\begin{tabular}{|c|c|c|c|}
\hline Senyawa & $\begin{array}{c}\text { Komposisi } \\
(\%)\end{array}$ & Unsur & $\begin{array}{c}\text { Komposisi } \\
(\%)\end{array}$ \\
\hline $\mathrm{SiO}_{2}$ & 65.64 & $\mathrm{Si}$ & 30.69 \\
\hline $\mathrm{TiO}_{2}$ & 0.259 & $\mathrm{Ti}$ & 0.155 \\
\hline $\mathrm{Al}_{2} \mathrm{O}_{3}$ & 6.66 & $\mathrm{Al}$ & 3.52 \\
\hline $\mathrm{Fe}_{2} \mathrm{O}_{3}$ & 4.15 & $\mathrm{Fe}$ & 2.89 \\
\hline $\mathrm{MnO}$ & 0.0679 & $\mathrm{Mn}$ & 0.0526 \\
\hline $\mathrm{CaO}$ & 9.75 & $\mathrm{Ca}$ & 6.97 \\
\hline $\mathrm{MgO}$ & 2.78 & $\mathrm{Mg}$ & 1.68 \\
\hline $\mathrm{Na}_{2} \mathrm{O}$ & 1.00 & $\mathrm{Na}$ & 0.745 \\
\hline $\mathrm{K}_{2} \mathrm{O}$ & 1.90 & K & 1.58 \\
\hline $\mathrm{P}_{2} \mathrm{O}_{5}$ & 0.132 & $\mathrm{P}$ & 0.0576 \\
\hline $\mathrm{SO}_{3}$ & 0.476 & S & 0.191 \\
\hline LOI & 6.86 & - & - \\
\hline $\mathrm{ZnO}$ & 0.0101 & $\mathrm{Zn}$ & 0.0081 \\
\hline $\mathrm{CuO}$ & 0.0062 & $\mathrm{Cu}$ & 0.0050 \\
\hline $\mathrm{SrO}$ & 0.0714 & $\mathrm{Sr}$ & 0.0604 \\
\hline $\mathrm{V}_{2} \mathrm{O}_{5}$ & 0.0132 & V & 0.0074 \\
\hline $\mathrm{Cr}_{2} \mathrm{O}_{3}$ & 0.0314 & $\mathrm{Cr}$ & 0.0215 \\
\hline $\mathrm{BaO}$ & 0.0534 & $\mathrm{Ba}$ & 0.0478 \\
\hline $\mathrm{Rb}_{2} \mathrm{O}$ & 0.0086 & $\mathrm{Rb}$ & 0.0079 \\
\hline $\mathrm{Ga}_{2} \mathrm{O}_{3}$ & 0.0018 & $\mathrm{Ga}$ & 0.0002 \\
\hline
\end{tabular}

Tabel 2 Hasil analisis fire assay dan ICP

\begin{tabular}{|c|c|c|c|}
\hline Elemen & Kadar & Elemen & Kadar \\
\hline $\mathrm{Au}$ & $5.2 \mathrm{ppm}$ & $\mathrm{Cd}$ & $\begin{array}{c}<0.05 \\
\mathrm{ppm}\end{array}$ \\
\hline $\mathrm{Ag}$ & $<0.5 \mathrm{ppm}$ & $\mathrm{Co}$ & $<0.1 \mathrm{ppm}$ \\
\hline $\mathrm{Al}$ & $<0.01 \%$ & $\mathrm{Cr}$ & $<5 \mathrm{ppm}$ \\
\hline $\mathrm{As}$ & $2 \mathrm{ppm}$ & $\mathrm{Cu}$ & $2 \mathrm{ppm}$ \\
\hline $\mathrm{B}$ & $<5 \mathrm{ppm}$ & $\mathrm{Fe}$ & \\
\hline $\mathrm{Ba}$ & $<10 \mathrm{ppm}$ & $\mathrm{Ga}$ & $<2 \mathrm{ppm}$ \\
\hline $\mathrm{Be}$ & $<5 \mathrm{ppm}$ & $\mathrm{Hg}$ & $<5 \mathrm{ppm}$ \\
\hline $\mathrm{Bi}$ & $<2 \mathrm{ppm}$ & $\mathrm{In}$ & $<5 \mathrm{ppm}$ \\
\hline $\mathrm{Ca}$ & $<0.01$ & $\mathrm{~K}$ & $0.22 \%$ \\
& $\mathrm{ppm}$ & & \\
\hline
\end{tabular}

Berdasarkan hasil analisis fire assay, didapatkan bahwa kadar Au dalam sampel bijih adalah 5,2 ppm dan kadar Ag adalah <0,5 ppm.
Sedangkan untuk preg-robbing test, sampel bijih memiliki sifat preg-robbing, yaitu bijih memiliki kecenderungan untuk mengambil kembali kompleks $\mathrm{Au}(\mathrm{CN})_{2}^{-}$yang terlarut di dalam larutan sehingga dapat terjadi penurunan ekstraksi emas pada jam tertentu. Karakteristik preg-robbing ini biasanya disebabkan oleh keberadaan karbon dalam bijih, untuk sampel bijih diketahui bahwa karbon hadir dalam bentuk mineral kalsit $\left(\mathrm{CaCO}_{3}\right)$. Karbon merupakan salah satu carbonaceous matter dalam bijih juga dapat menyebabkan emas terperangkapdi dalamnya sehingga menghalangi pelindian emas.

\section{KESIMPULAN}

Komposisi bijih sampel terdiri dari kuarsa, serta sedikit mineral sulfide yaitu kalkopirit, spalerit, pirit, dan kovelit. Dalam bijih ini juga ditemukan kalsit, yang dapat berpotensi menyebabkan sifat preg-robbing. Mineral emas secara megaskopis tidak terlihat, akan tetapi pada pengamatan mineragrafi ditemukan keberadaan emas dalam bentuk mineral electrum. Mineral electrum yang ditemukan jumlahnya sangat sedikit dan memiliki kenampakan warna putih krem, berukuran sangat halus hingga $5 \mu \mathrm{m}$ yang tersebar secara acak dan terinklusi dalam kuarsa. Berdasarkan hasil analisis fire assay, didapatkan bahwa kadar Au dalam sampel bijih adalah 5,2 ppm dan kadar Ag adalah <0,5 ppm.

\section{UCAPAN TERIMA KASIH}

Ucapan terima kasih ditujukan kepada Beasiswa Pendidikan Pascasarjana dalam Negeri (BPPDN) Kemenristek DIKTI, dan PT. Citra Palu Minerals dalam membantu penyelesaian penelitian ini.

\section{DAFTAR PUSTAKA}

[1] Achmadi, S. S. 1990. Kimia Kayu. Departemen Pendidikan dan Kebudayaan. Direktorat Jenderal Pendidikan Tinggi. Pusat Antar Universitas. Ilmu Hayat. Institut Pertanian Bogor.

[2] "Activated Carbon 101", http://www.carbochem.com

[3] Adams, M. D. 2005. Advances in Gold Ore Processing. Elsevier.

[4] Adhikari, B. B., Gurung, M., Alam, S., Tolnai, B., Inoue, K., 2013. Kraft mill lignin A potential source of bio-adsorbents for gold recovery from acidic chloride solution. Chemical Engineering Journal 231, 190-197.

[5] "Air Filtration", http://buildingprotection.rdecom.army.mil/bas iclaf.htm 
[6] Alekhina, M., Ershova, O., Ebert, A., Heikkinen, S., Sixta, H., 2014. Softwood kraft lignin for value-added applications: Fractionation and structural characterization. Industrial Crops and Products 66, 220-228.

[7] Al-Ghoutia, M. A., Li, J., Salamh, Y., AlLaqtah, N., Walkeb, G., Ahmad, M. N. M., 2009. Adsorption mechanisms of removing heavy metals and dyes from aqueous solution using date pits solid adsorbent. Journal of Hazardous Materials 176, 510-520.

[8] Al-Saidi, H. M., 2013. The fast recovery of gold(III) ions from aqueous solutions using raw date pits: Kinetic, thermodynamic and equilibrium studies. Journal of Saudi Chemical Society, xxx, xxx-xxx

[9] Antoine Duval, Martin Lawoko. 2014. A review on lignin-based polymeric, micro- and nano-structured materials. Reactive \& Functional Polymers 85 (2014) 78-96.

[10] Awual, M. R., Khaleque, M. A., Ferdows, M., Chowdhury, A. M. F., Yaita, T., 2013. Rapid recognition and recovery of gold (III) with functional ligand immobilized novel mesoporous adsorbent. Microchemical Journal 110, 591-598

[11] Behin, J. an Azizian, S. (2004), Kinetic models of sorption: a theoretical analysis, Journal of Colloid and Interface Science, 276(1): 47-52.

[12] Braun, Patrick. Method Manual Volume 1 Gold Analysis in Alkaline Cyanide Solutions. Society of Mineral Analysts Sparks, Nevada.

[13] Cateto, C. A., Barreiro, M. F., Rodrigues, A. E., Belgacem, M. N., 2011. Kinetic study of the formation of lignin-based polyurethanes in bulk. Reactive \& Functional Polymers 71, 863-869.

[14] Chakar, F. S., Ragauskas, A. J., 2004. Review of current and future softwood kraft lignin process chemistry. Industrial Crops and Products 20, 131-141.

[15] Chandra and M. Z. Mubarok. 2016. On the Use of Lignin-based Biopolymer in Improving Gold and Silver Recoveries During Cyanidation Leaching. Minerals Engineering 89, 1-9.

[16] Duval, A., Lawoko, M., 2014. A review on lignin-based polymeric, micro- and nanostructured materials. Reactive \& Functional Polymers 85, 78-96.

[17] Fengel, D. dan G. Wegener. 1995. Kayu : Kimia, Ultrastruktur dan Reaksi. Gadjah Mada Press University. Yogyakarta.

[18] Fletcher, Asleigh, (2008), "Porosity and Sorption

Behaviour",www.staff.ncl.ac.uk/a.j.fletcher/ad sorption.htm
[19] Gomes, C. P., Almeida, M. F., Loureiro, J. M., 2000. Gold recovery with ion exchange used resins. Separation and Purification Technology 24, 35-57.

[20] Habashi,F., A Textbook of hydrometallurgy,metallurgie extractive, Quebec, Enrc Canada 1993.

[21] Judoamidjojo, R. M., E.G. Said dan L. Hartoto. 1989. Biokonversi. Departemen Pendidikan dan Kebudayaan. Direktorat Pendidikan Tinggi. Pusat Antar Universitas Bioteknologi, Institut Pertanian Bogor. Bogor.

[22] Kinoshita, T., Akita, S. S., Ozawa, S., Nii, S., Kawaizumi, F., Takahashi, K., 2004. Continuous Recovery of Gold(III) via Foam Separation with NonionicSurfactant. Journal of Minerals \& Materials Characterization \& Engineering, Vol. 3, No.1, 53-63.

[23] Kirk R. E. dan D. F. Othmer.1952. Encyclopedia of Chemical Technology. Vol.8. Pp.327-338. The Interscience Encyclopedia, Inc., New York.

[24] Lelifajri. 2010. Adsorpsi Ion Logam Cu(II) Menggunakan Lignin dari Limbah Serbuk Gergaji. Jurnal Rekayasa Kimia dan Lingkungan, Vol. 7, No. 3, 126-129.

[25] Li, Z., Ge, Y., Wan, L., 2014. Fabrication of a green porous lignin-based sphere for the removal of lead ions from aqueous media. Journal of Hazardous Materials 285, 77-83.

[26] Marsden, John and C. Iain House. 2006. The Chemistry of Gold Extraction, 2nd edition. Society for Mining, Metallurgy and Exploration, Inc. : USA.

[27] Mc. Cabe, W. Smith,J., Harriot,P. 1993. "Unit Operation of Chemical Engineering”, 5th ed, Mc Graw-Hill, inc. New York

[28] McKay, Gordon; C. K., Danny; Tsang, David H. K.; Potter, John F., (2003), “Applications of Multipore Model for the Mechanism Identification during theAdsorption of Dye on Activated Carbon and Bagasse Pith", Langmuir, 19, 722-730.

[29] Ouyang X, Qiu X, Chen P. 2006. PhysicoChemical Characterization of Calsium Lignosulfonate. A Potentially Useful Water Reducer Colloids and Surfaces A: PhysicoChem. Eng. Aspects. 283-286;489-497.

[30] Pionera Biopolymer. Pioneering Solution in Mineral Processing. 2012.

[31] Rahmawati, N. 1999. Struktur Lignin Kayu Daun Lebar dan Pengaruhnya terhadap Laju Delignifikasi. Tesis. Program Pasca Sarjana Institut Pertanian Bogor. Bogor.

[32] Rosen M. J. Dan M. Dahanayake. 2000. Industrial Utilizasion of Surfactant : Principle and Practice. Illinois AOCS Press, Champaign. 
[33] Salminah, M. 2001. Karakteristik Lignin Hasil Isolasi Larutan Sisa Pemasak Pulp Proses Semi Kimia pada Berbagai Tingkat pH. Skripsi. Jurusan Teknologi Hasil Hutan Fakultas Kehutanan, Institut Pertanian Bogor. Bogor.

[34] Seader,J.D., Henley,E.J. (1998). "Separation Process Principles". New York, John Wiley $\&$ Sons, Inc.

[35] Stewart, D., 2008. Lignin as a base material for materials applications: Chemistry, application and economics. Industrial Crops and Products 27, 202-207

[36] Syukri. 1999. Kimia Dasar 3. Bandung : Institut Teknologi Bandung.

[37] Watkins, D., Nuruddin, M., Hosur, M., Narteh, A. T., Jeelani, S., 2014. Extraction and characterization of lignin from different biomass resources. J Mater Res Technol . 2014; x x x(x x):xxx-xxx. 